\title{
Severe gonarthrosis without pain and disability: A
} case report

\author{
Ağrısız ve kısıtlılık oluşturmayan ileri evre \\ gonartroz: Olgu sunumu
}

ÜlkÜ Sur Ünal' ${ }^{1}$, Ömer Kays Ünal ${ }^{2}$

${ }^{1}$ Zeynep Kamil Family Medicine Health Center, Family Medicine Clinic, Istanbul, Turkey

${ }^{2}$ Maltepe University Faculty of Medicine, Orthopedics and Traumatology Department, Istanbul, Turkey

Submitted Date: 19 Ekim 2021, Accepted Date: 25 Ekim 2021
Correspondence: Ömer Kays Ünal

Maltepe University Faculty of Medicine, Orthopedics and Traumatology

Department, Istanbul, Turkey

e-mail: omerkays@gmail.com

ORCID ID:

USU 0000-0003-4758-4413

OKU 0000-0002-9445-1552

\section{SUMMARY}

Diz Osteoartriti (gonartroz), diz bölgesindeki kronik ağrının en yaygın nedenlerinden biridir. Gonartrozda tip II kollajenin bozulması, kıkırdak yıkımı, sinovit ve kemik iliği lezyonları tipik olarak belirgin ağrıya sebep olur. Diz eklemindeki bu değişiklikler, zaman içinde eklem hareket açıkığında önemli kısıtlılıklara ve yürüme bozukluklarına yol açmaktadır. Bu semptomların zamanla ilerlemesi ile hastanın yaşam kalitesi giderek düşmekte ve ileri gonartroz vakalarında hastalar bakıma muhtaç hale gelebilmektedir. Bu yazıda diz bölgesinde ağrısız ve hareket kısıtlılı̆̆ olmayan ileri evre gonartroz olgusu sunulmaktadır.

Keywords: Ağrı, diz eklemi, hareket kısıtlılığı, osteoartirit

\section{ÖZET}

Knee Osteoarthritis (gonarthrosis) is one of the most common causes of chronic pain in the knee area. In gonarthrosis, disruption of type II collagen, cartilage destruction, synovitis, and bone marrow lesions typically cause significant pain. These changes in the knee joint lead to significant limitation of range of motion and gait disturbances over time. With the progression of these symptoms over time, the quality of life of the patient gradually decreases and patients may become in need of care in advanced cases of gonarthrosis. In this report, a case of advanced gonarthrosis without pain and limitation of movement in the knee region is presented.

Anahtar kelimeler: Knee joint, osteoarthritis, pain, stiffness 


\section{INTRODUCTION}

Knee osteoarthritis, in other words, gonarthrosis, is a frequent chronic crippling knee joint disease, especially in the elderly, which causes considerable pain, stiffness, and lower extremities disability that significantly affect the patients' self-independence and quality of life $(1,2)$. Pain is the cardinal symptom of osteoarthritis (OA) and impacts physical function, quality of life, mental health, and health service use $(3,4)$. The main intervention goals are pain reduction and improvement of physical function (5). However, does gonarthrosis always cause pain? We report a case of severe gonarthrosis without pain and disability.

\section{CASE REPORT}

A 57-year-old woman presented to our clinic with left ankle pain after ankle sprain, which occurred 3 weeks ago. There were no other complaints. The patient's weight was $104 \mathrm{~kg}$, and her height was $171 \mathrm{~cm}$. BMI was 35,6 (Class II obesity) (6). She did not have any other systemic diseases. Her past medical and family history was unremarkable. She was not taking any medications at the time of admission.

Physical examination revealed that her left knee has 100 extension deficiency. Bilateral knee flexion range was 0-1100, right knee extension was 00, and left knee extension was -100 . The bilateral knee range of motion (ROM) and patellar tilt test was painless. Crepitus was observed at both knees. We evaluated bilateral knee pain and function with IKDC Score, Knee Injury and Osteoarthritis Score (KOOS), WOMAC Score, Knee Society Score (KSS), Visual Analog Score (VAS) (Table 1) (7-11). Despite a slight decrease in knee function scores, the patient did not have knee pain or disability due to radiologically detected knee osteoarthritis. Additionally, other conditions which could mask the pain sensation such as, polyneuropathy or spinal cord pathologies, were not detected. Bilateral bearing knee X-ray was performed and revealed severe chondral degeneration, knee joint space narrowing, osteophyte formation, and subchondral sclerosis.

Table 1. Functional knee scores and pain score

\begin{tabular}{lc} 
Functional Knee Scores & Score \\
\hline IKDC Score $^{*}$ & 76,1 \\
Knee Injury and Osteoarthritis Score $^{\dagger}$ & 80,4 \\
WOMAC Score $^{\dagger}$ & 79,5 \\
Knee Society Score & 77 \\
Visual Analog Score & 0
\end{tabular}

The patient was informed that she had radiologically advanced osteoarthritis in the knee joint. Since the patient had no complaints, no medication was prescribed; however, lifestyle changes and knee ROM exercises were recommended because of radiological detection of knee osteoarthritis in the knee joint.

\section{DISCUSSION}

$\mathrm{OA}$ is the most common joint disease worldwide that appears to originate in the cartilage and affects the underlying bone, soft tissues, and synovial fluid and is mostly affecting the hand and large weight-bearing joints such as the knee $(12,13)$. As a polymorphic disease with a variety of clinical presentations, $O A$ is challenging to define rigorously. A commonly encountered definition of OA describes "...a heterogeneous group of conditions that leads to joint symptoms and signs which are associated with defective integrity of articular cartilage, in addition to related changes in the underlying bone and at the joint margins" (14). Patients suffering from OA often complain of pain on movement, typically occurring when movement is initiated or when the patient begins to walk. The pain is often described as a dull ache. As OA progresses, the pain becomes continuous, and the functionality of the joint is severely impaired. The main goal of diagnostic evaluation is to demonstrate the presence of OA unequivocally or else to rule it out. A precise diagnosis enables precise treatment. The major elements of the diagnostic evaluation are the history, physical examination, imaging studies, and, in some cases where special questions arise, laboratory testing. X-ray findings are usually sufficient for diagnosis and determining severity. The Kellgren and Lawrence system is a widely used method for classifying the severity of knee OA with X-ray findings (15) (Table 2).

Table 2. The Kellgren and Lawrence osteoarthritis grading system

\begin{tabular}{cl} 
Grade & Explanation \\
\hline 1 & joint space narrowing (less than $3 \mathrm{~mm})$ \\
2 & joint space obliteration \\
3 & minor bone attrition $(0-5 \mathrm{~mm})$ \\
4 & moderate bone attrition $(5-10 \mathrm{~mm})$ \\
5 & severe bone attrition (more than $10 \mathrm{~mm})$ \\
\hline
\end{tabular}

According to the Knee OA Criteria of the American College of Rheumatology (9), a person without knee pain cannot be diagnosed with knee osteoarthritis; however, although there was no pain in the presented case, it is considered as grade 4 bilateral gonarthrosis (Kellgren and Lawrence) according to direct radiography findings. (Figure 1).

In many studies in the literature, pain is stated as an invariable component of knee osteoarthritis $(16,17)$. However, some studies reveal a discordance between pain and knee osteoarthritis in a study combining two cohorts. Neogi et al. (18) showed that pain was more correlated with joint space narrowing than with the presence of osteophytes. Another study showed that bone marrow edema and synovitis are structural changes that are closely related to pain. In contrast, osteophytes, bone cysts, and ligament structure changes are not closely associated with OA pain (19). 

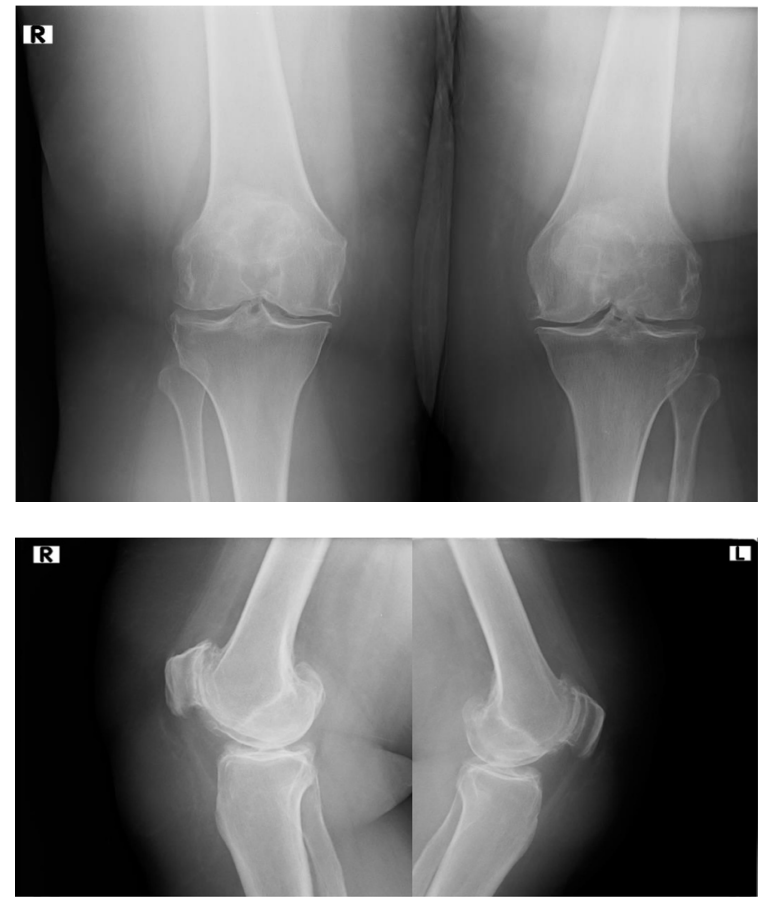

Figure 1. Bearing bilateral knee x-ray

\section{CONCLUSIONS}

This case report revealed that severe osteoarthritic findings on X-ray may not always cause the main symptoms of gonarthrosis. Therefore, perhaps we should question the necessity of knee pain for the diagnosis of gonarthrosis. Clinical presentation, physical examination, and imaging need to be evaluated together before diagnosing gonarthrosis and planning a treatment regimen. There is a need for meta-analyses with larger case series on this subject.

\section{Consent}

Written informed consent was obtained from the patient for publication of this case report and any accompanying images.

Author Contributions: Working Concept/Design: AAH, YU, Data Collection: AAH, YU, Data Analysis / Interpretation: AAH, YU, Text Draft: AAH, YU, NG Critical Review of Content: $A A H, Y U$, Final Approval and Responsibility: $A A H$, YU, Material and technical support: AAH, YU, Supervision: AAH

Conflict of Interest: The authors state that there is no conflict of interest regarding this manuscript.

Financial Disclosure: The authors declared that this study has received no financial support.

\section{REFERENCES}

1. Ringdahl E, Pandit S. Treatment of knee osteoarthritis. [Summary for patients in Am Fam Physician. 2011 Jun 1;83(11):1294

2. Laroche D, Morisset C, Fortunet C, Gremeaux V, Maillefert JF, Ornetti P. Biomechanical effectiveness of a distractionrotation knee brace in medial knee osteoarthritis: Preliminary results. Knee. 2014 Jun;21(3):710-6.

3. Verbrugge LM, Lepkowski JM, Konkol LL. Levels of disability among U.S. adults with arthritis. J Gerontol. 1991 Mar;46(2):71-83

4. Dominick KL, Ahern FM, Gold CH, Heller DA. Healthrelated quality of life among older adults with arthritis. Health and Quality of Life Outcomes. 2004 Jan 13;2:5.

5. Bennell KL, Hall M, Hinman RS. Osteoarthritis year in review 2015: Rehabilitation and outcomes. Osteoarthritis and Cartilage. 2016 Jan;24(1):58-70.

6. Nuttall FQ. Body Mass Index: Obesity, BMI, and Health: A Critical Review. Nutr Today. 2015 May;50(3):117-128.

7. Roos EM, Roos HP, Lohmander LS, Ekdahl C, Beynnon BD. Knee Injury and Osteoarthritis Outcome Score (KOOS)-development of a self-administered outcome measure. J Orthop Sports Phys Ther. 1998 Aug;28(2):88-96.

8. McCormack HM, Horne DJL, Sheather S. Clinical applications of visual analogue scales: a critical review. Psychol Med. 1988 Nov;18(4):1007-19.

9. Peat G, Thomas E, Duncan R, Wood L, Hay E, Croft P. Clinical classification criteria for knee osteoarthritis: performance in the general population and primary care. Ann Rheum Dis. 2006 Oct;65(10):1363-7.

10. Insall JN, Dorr LD, Scott RD, Scott WN. Rationale of The Knee Society clinical rating system. Clinical Orthopaedics and Related Research. 1989;(248):13-4.

11. Anderson AF, Irrgang JJ, Kocher MS, Mann BJ, Harrast JJ. The International Knee Documentation Committee Subjective Knee Evaluation Form: normative data. Am J Sports Med. 2006 Jan;34(1):128-35.

12. Michael J. W., Schlüter-Brust K. U., Eysel P. The epidemiology, etiology, diagnosis, and treatment of osteoarthritis of the kneeDtsch Arztebl Int. 2010 Mar;107(9):152-62.

13. Flugsrud GB, Nordsletten L, Reinholt FP, Risberg MA, Rydevik K, Uhlig T. Artrose. Tidsskrift for den Norske Laegeforening. 2010;130(21):2136-40.

14. Altman R, Asch E, Bloch D, Bole G, Borenstein D, Brandt $\mathrm{K}$, et al. Development of criteria for the classification and reporting of osteoarthritis. Classification of osteoarthritis of the knee. Arthritis Rheum. 1986 Aug;29(8):1039-49.

15. Petersson IF, Boegård T, Saxne T, Silman AJ, Svensson B. Radiographic osteoarthritis of the knee classified by the Ahlback and Kellgren and Lawrence systems for the tibiofemoral joint in people aged 35- 54 years with chronic knee pain. Annals of the Rheumatic Diseases. 1997;56(8):493-6.

16. Lanyon P, O'Reilly S, Jones A, Doherty M. Radiographic assessment of symptomatic knee osteoarthritis in the community: definitions and normal joint space. Ann 
Rheum Dis. 1998 Oct;57(10):595-601.

17. Williams DA, Farrell MJ, Cunningham J, Gracely RH, Ambrose K, Cupps T, et al. Knee pain and radiographic osteoarthritis interact in the prediction of levels of self-reported disability. Arthritis Rheum. 2004 Aug 15;51(4):558-61.

18. Neogi T, Felson D, Niu J, Nevitt M, Lewis CE, Aliabadi P, et al. Association between radiographic features of knee osteoarthritis and pain: Results from two cohort studies. BMJ. 2009 Aug 21;339:b2844.

19. L Torres, D D Dunlop, C Peterfy, A Guermazi, P Prasad, $\mathrm{K} W$ Hayes, et al. The relationship between specific tissue lesions and pain severity in persons with knee osteoarthritis. Osteoarthritis Cartilage. 2006 Oct;14(10):1033-40. 